J Sci.Univ.Kelaniya 4 (2008): 21-35

\title{
SHOULD SHRIMP CULTURE BE BLAMED? THE INTERACTIONS OF DIVERSE NATURAL RESOURCES UTILIZATION IN SHRIMP CULTURE
}

\author{
U. P. K. EPA AND M. J. S. WIJEYARATNE
}

Department of Zoology, University of Kelaniya, Kelaniya, Sri Lanka

E-mail: epa@kln.ac.lk

\begin{abstract}
Due to high demand and high price received for the produce and also due to capture fishery can no longer meet the demand, the shrimp culture industry is rapidly growing, especially in coastal belt of Asia where most of the environmental factors are conducive. In recent years, number of problems associated with the expansion of the industry has been identified. Therefore, the shrimp culture is considered to be environmentally damaging and unfriendly and as such it has been the target of criticism by environmental conservation lobby groups. As a result of such criticism the general public is of the impression that the shrimp farming is dangerous to the environment and to the economic development of a country. This paper explores the popular negative image of shrimp pond culture, focusing on the diverse natural resources utilization by the industry in tropical coastal areas.
\end{abstract}

Keywords: Shrimp, environment, mangroves, pollution

\section{INTRODUCTION}

World aquaculture (food fish and aquatic plants) has grown significantly during the past half-century. From a production of below 1 million tones in the early 1950s, aquaculture production was reported to have increased to 59.4 million tones in 2004, with a value of US\$ 70.3 billion. Aquaculture continues to grow more rapidly than all other animal food-producing sectors. Worldwide, this sector has grown at an average rate of 8.8 percent per year since 1970, compared with only 1.2 percent for capture fisheries and 2.8 percent for terrestrial farmed meat production systems over the same period (FAO, 2007). In global terms, some 99.8 percent of cultured aquatic 
plants, 97.5 percent of cyprinids, 87.4 percent of penaeids (shrimps and prawns) and 93.4 percent of oysters come from the Asia and the Pacific.

Shrimp production from aquaculture has expanded readily from $1495950 \mathrm{mt}$ in 2002 to $2476023 \mathrm{mt}$ in 2004 (FAO, 2007). Thailand was the world leading producer of farmed shrimp in the year 2000, with a production of 299,700 mt, followed by China (217,994 mt), Indonesia (138,023 mt), India (52,771 mt), Ecuador (50,110 $\mathrm{mt}$ ) and the Philippines (41,803 mt) (FAO, 2002). Malaysia, Vietnam, Taiwan and Bangladesh also have active shrimp farming industries. Myanmar, Cuba, Madagascar and Sri Lanka have significant number of shrimp farms, and there are shrimp farms throughout Central and South America. Honduras Panama, Guatemala, Colombia and Peru have small areas devoted for shrimp farming. International trade for fresh and frozen shrimp is in the range of US\$ 8.5 - 10 billion (FAO, 2002). In Asia most shrimp are exported to Japan, USA and European Economic Community (EEC) countries (Yamamoto, 1992; Josupeit, 2001). New markets have also emerged in Asia i.e. in Republic of Korea, Singapore and Hong Kong (Anon., 2001).

It has been estimated that the industry is worth US\$ 20 billion in Asia. Infrastructure investment in ponds alone is worth around US\$ 11.5 billion (Singh, 1999). High profitability and generation of foreign exchange have been a major driving force in the global expansion of shrimp culture, attracting both national and international development agencies (Primavera, 1997; Shang \& Tisdell, 1997). The acceleration in shrimp culture activity in the early 1990s was influenced by a combination of factors. Economic conditions encouraged a rapid increase in demand for shrimp while simultaneous new innovative culture technologies were being developed. Among the most important factors influencing the demand for shrimp were (1) rapid income growth in areas where shrimp was a popular premium food (primarily in Asia and some parts of Europe), (2) a shift in U.S. and European consumer preference away from traditional protein sources (e.g., red meat) to seafood, and (3) adjustments in currency relative to the U.S. dollar that encouraged shrimp consumption in Japan, China, and Europe.

Shrimp farming traces its origin to Southeast Asia, where for centuries farmers raised incidental crops of wild shrimp in tidal ponds. The technology of shrimp larval rearing was first developed in 1934 by Hudinaga (Hudinaga, 1942 cited by Liao, 1996). Although the pioneering research and development was conducted in the 1930s on the cold water Penaeus japonicus, the explosive growth of shrimp farming in the last decades has been associated with the tropical giant tiger prawn, P. monodon 
(Primavera, 1998). In 1968, Liao and his colleagues artificially propagated black tiger prawn (P. monodon) (Liao, 1996). In particular, artificial breeding and large-scale production of formulated feed, made it possible for shrimp culture to develop on a large scale. In the early 1960s, the first commercial farms were built in the Seto Inland Sea of Japan.

\section{Cultured shrimp species}

Of the cultured shrimp species, only three ( $P$. monodon, $P$. chinensis, and $P$. vannamei) were produced in quantities over $100,000 \mathrm{mt}$ per annum. $P$. monodon dominates the world cultured shrimp production with 575,842 mt (value US\$ 3,651,783 x 103) in 1999 followed by P. vannamei and P. chinensis with 187,224 mt (value US\$1,062,775 x 103) and 171,972 mt (value US\$1,126,447 x 103) respectively (FAO, 2002). Some of the other cultured species are Banana prawn (P. merguiensis), Brown tiger prawn ( $P$. esculentus), Blue shrimp ( $P$. stylirostris), Fleshy prawn ( $P$. chinensis), Green tiger shrimp ( $P$. semisulcatus), Indian white shrimp ( $P$. indicus), Kuruma prawn ( $P$. japonicus), Northern white shrimp ( $P$. setiferus), Red tail prawn ( $P$. penicillatus) and Southern white shrimp (P. schmitti).

\section{Culture procedures in shrimp farming}

\section{Hatchery operations}

Compared to many livestock industries, shrimp farming is still in the early stages of domestication and selective breeding. The source of brood stock animals varies widely, as both wild and pond reared animals are used in commercial systems. However, many hatcheries still rely on wild shrimp for the production of seed stock (Weidner \& Rosenberry, 1992; Kautsky et al., 2001). They either capture wild juveniles that are stocked directly into nursery or grow out ponds, or they spawn egg laden females collected from sea at hatchery.

Hatcheries come in range of sizes and levels of technical sophistication, from small, simple, family run systems to major industrial scale installations employing managers, scientists, and technicians. All operate on the principles of maintenance of high quality water, health monitoring, and appropriate feeding (diatoms, brine feeds, micro feeds). 


\section{Grow out culture}

Shrimp post larvae collected from wild or hatchery reared are stocked in the culture facilities. Once grow out ponds are stocked with juvenile shrimp, it takes 3 - 6 months to produce a crop of market size shrimp. Shrimp have been successfully reared in a variety of commercial production systems, including net or pen enclosures, traditional earthen ponds, concrete-, block-, or palstic- lined ponds with earthen or concrete bottoms, block or plastic lined round pond systems, and controlled environments (covered) tanks or raceways (Clifford, 1992; Kautsky et al., 2000).

Shrimp grow out systems may be classified into extensive, semi-intensive, and intensive, with stocking rates of $1-3,3-10$ and 10-50 post larvae $\mathrm{m}^{-2}$, respectively (Primevera, 1998). In extensive systems, growth of the shrimp relies on natural pond fertility. Fertilizer or shrimp feeds are seldom used. The demand for water of these systems is considerably lower than that of the more intensive systems. Semi-intensive culture was the predominant production strategy although socking density varied by an order of magnitude and pond size varied by nearly two orders of magnitude (Hopkins \& Villalon, 1992). Semi intensive shrimp culture accounts for about $42 \%$ of all world farmed shrimp production and utilized about $28 \%$ of total shrimp culture area (Menasveta \& Fast, 1998). ). In intensive shrimp culture, stocking densities are usually $>30$ post larvae $\mathrm{m}^{-2}$ and water exchange and aeration of ponds are essential as the stock biomass increases. The appropriate pond management strategy is determined by species, stocking density, production goals, and economic objectives of the producer (Clifford, 1985; Kautsky et al., 2000).

\section{Interaction of shrimp culture with other coastal resources uses}

Shrimp culture, as with other agriculture, industrial and aquaculture enterprises, requires natural resources. Figure 1 shows the natural resources utilization by shrimp culture in the broader context. 


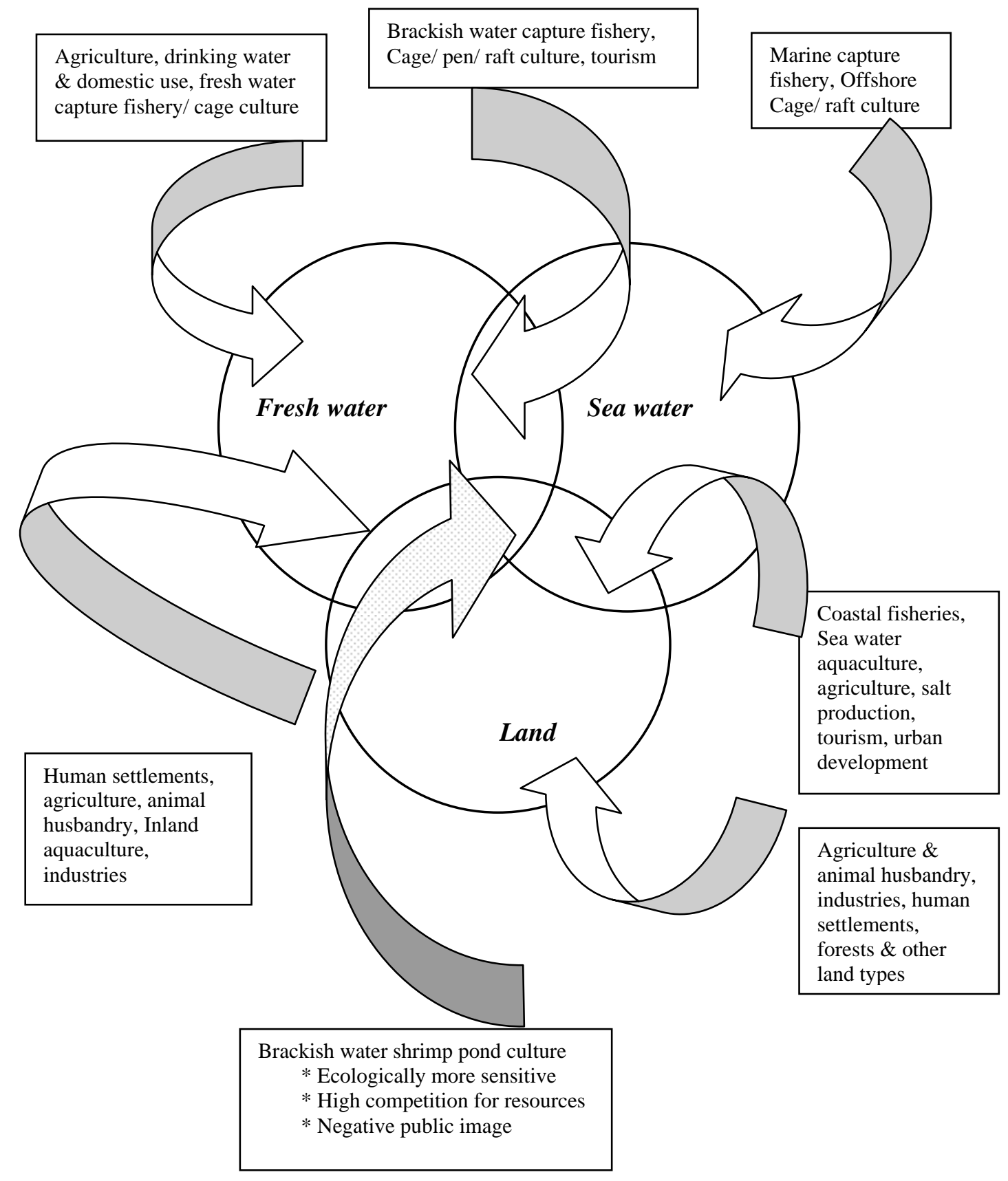

Figure 1: A schematic representation of the interactions of diverse natural resources utilization in shrimp culture 


\section{Water use}

Seawater, river water/brackish water and ground water are the major water types used in shrimp culture operations. This clearly demonstrates that shrimp pond culture has not ignored any type of water that is available in the coastal environment. Shrimp culture by virtue of the fact happens to be located in coastal areas, with a good supply of water from the sea as well as inland and consequently have to compete with other water users. There is a great demand for same water resources for human consumption, agriculture, and other industries and especially for coastal fisheries. Therefore, high competition for available water resources within coastal area is unavoidable. Especially a high demand can be expected for freshwaters as it is not readily available in most of the coastal areas in Asia. Use of brackish water in shrimp culture ponds and subsequent discharge of effluents to the estuaries and lagoons pollutes the aquatic environment and directly affects coastal fisheries. It also indirectly limits the access to open waters by fishermen.

The traditional method of removing wastes from ponds has been by frequent water exchange. This pollutes natural waterways and is considered to be environmentally unfriendly. According to a research done in Australia, nitrogen and phosphorus inputs to the aquatic environment from shrimp farming are small and treatable compared to other anthropogenic sources (McPee, 2001). Aquaculture Foundation of India (AFI), stated that the chemical industry, heavy metal industries and agricultural pesticide residues are far more dangerous in terms of pollution impact compared to the bio degradable waste of the shrimp culture industry (Ninawe, 1999; Kautsky et al., 2001), a factor that could not be different in most of the other countries. Increasing urbanization, industrialization and chemical use in agriculture is making it difficult to find pollution free waters in many coastal areas in both Asia (Chua et al., 1989) and Latin America (Aitken, 1990; Beveridge et al., 1997). In a way this has restricted the further development of shrimp culture which need unpolluted water for hatchery and grow out operations.

Despite high amounts of organic matter added to shrimp culture ponds, principally as pelleted feeds, the mean bacterial numbers and nutrient concentrations (i.e. organic carbon, nitrogen and phosphorus) in the sediment in shrimp ponds are known to be similar to those found in mangrove sediment (Burford et al., 1998; 
Kautsky et al., 2001). For example, according to Frederiksen et al. (1998), the nitrogen and organic carbon contents in shrimp pond waste is lower than those in natural mangrove soil from Klong Ngao, Thailand. However, there is still a lack of understanding of functioning of ecosystems or how they respond to perturbation in shrimp farming areas. These factors however, do not get the attention of the public. Without due consideration for positive factors, complains made by other resource users have been highlighted by the popular press.

Introduction of exotic non native shrimp into waters is considered environmentally undesirable, but there has not been any documentation of uncontrolled proliferation of new shrimp species resulting from importation. However, imported shrimp had introduced new pathogens into several countries in Latin America and Asia (Subasinghe \& Barg, 1998).

\section{Land use}

Macintosh \& Phillips (1992) summarized the principal land resources required for shrimp culture. According to them, the major land types are mangroves, other swampy lands, sand-flats/ salinas/ arid zones and agricultural lands that are adjacent to the coastal areas. The coastal area of Southeast Asia is considered to be endowed with the world's most productive ecosystems such as coral reefs, mangroves and sea grass beds and with mineral and oil reserves in the continental shelf. There are many well established traditional industries that utilize these resources and because of that majority of economic activities in the region occur within $3 \mathrm{~km}$ seaward and $10 \mathrm{~km}$ landward along the shoreline. Among the coastal activities are fishing, mangrove logging, salt making, navigation, mineral and oil exploitation, coastal urbanization, industrialization, tourism and aquaculture (Thia-Eng, 1989; Kautsky et al., 2001). Therefore, high price and low availability of lands might have affected the development of shrimp culture industry. High investments on land have directed the farmers to practice intensive farming methods rather than traditional extensive methods and also venture into marginal lands. Development of shrimp pond culture in such a challenging environment would not be possible unless it has flexibility to current environmental and economical conditions. However, the claims made against the development of shrimp pond culture by other traditional land users has readily been accepted by the popular press without due consideration. The damage done by other 
traditional activities such as mangrove logging, dumping of wastes has not been received due attention recently because of the traditional nature of the problem.

Between 1 and 1.5 million ha of coastal lowlands in the world have been converted into shrimp aquaculture (Paez-Osuna, 2001). In Thailand $21 \%$ of new shrimp ponds were constructed in mangrove habitats (Kongkeo, 2001) while in Sri lanka 35\% farms were constructed in former wetland areas (Jayasinghe, 1995). In India most of the shrimp farms (85\%) are constructed in the saline shore zone, and thus the utilization of agricultural land accounted for only $15 \%$ of the total land (Ninawe, 1999). However, low productivity of agricultural lands coupled with few tolerable species available adjacent to coastal area due to high salinity is a factor that has not been taken into consideration by the environmental lobby groups. Actually shrimp culture has converted large area of land that has been considered unproductive into productive land and earns most important foreign exchange to the developing countries. However, for environmental and land availability reasons, new shrimp farms may increasingly have to look for more marginal sites. This trend will substantially increase the competition for the coastal land that has already been utilized by other enterprises.

\section{Mangrove destruction}

The expansion of aquaculture worldwide has caused significant environmental damage to coastal ecosystems (Folke \& Kautsky, 1992; Lin, 1995; Kautsky et al., 2001). Especially, the escalation of conversion of mangrove forests to brackish water fish and shrimp ponds is alarming (Folke \& Kautsky, 1992; Fegan, 1996; Macintosh, 1996; Pongthanpanich, 1996; Williams, 1997; Alongi et al., 1999; Paez-Osuna, 2001; Purwaka, 2002). However, there are also other factors responsible for mangrove destruction, which include human settlements, agriculture, use for fuel and timber and salt beds (Primavera, 1998; Chamberlain, 2001), and tourism (Chamberlain, 2001). Mangrove forests and their water ways also have long been used as convenient sites for the disposal of sewage and waste water in tropical countries (Robertson and Phillips, 1995).

Contrary to that, shrimp farming has been always considered as the major factor for mangrove destruction in the world. However, about $55-60 \%$ of the world's historic mangrove resources have been lost due to population pressures and for agriculture, urban development, logging and fuel. Assuming that all 1 million ha of shrimp ponds were converted from mangroves, then shrimp ponds would account for 
the destruction of only $6.2 \%$ of the global mangrove resource (Macintosh \& Phillips, 1992). However, the calculated overall loss due to shrimp farm development is less than 3\% (Chamberlain, 2001). In China and Vietnam shrimp ponds are found largely in non-mangrove areas and areas where mangroves had already been cleared for other purposes (Macintosh, 1996).

It is a widely accepted fact that removal of mangroves leads to a decline of estuarine and coastal fisheries. Declining of fish and shrimp catches in coastal area has been observed for decades due to other anthropogenic activities. However, now the total blame has been put on the shrimp culture as the industry is more visible and the destruction of mangroves caused by this industry is more recent. Despite a wide spread view to the contrary, research in Thailand has even shown that mangroves can be planted successfully in shrimp waste sludge dumped in to holding areas in the inter tidal zone around the shrimp farms (Macintosh, 1996).

\section{Wild seed and brood stock collection}

Declines in the abundance of wild post larvae have been reported from many countries, due to natural fluctuations and human influences. A decline of wild caught post larvae of $P$. monodon has been reported from India and Bangladesh (Silas, 1987). Subsequent reduction of shrimp fishery could be expected in such instances, which induces an economical uncertainty among shrimp fishers. In Bangladesh, expansion of shrimp farming into mangrove areas has led to reduction in fish catches and socioeconomic impacts on traditional coastal fisheries (Williams, 1997) and conflicts have arisen in some areas between rice farmers and shrimp culturists (Anon., 2000). Contrary to that, some of the shrimp producing countries such as Sri Lanka and Australia totally rely on hatchery bred shrimp larvae. Now the technology of artificial rearing of shrimp larvae is widespread and the collection of fry from wild could be expected to decline in near future.

\section{DISCUSSION}

Shrimp culture affects, one-way or other, most of the coastal land, and marine water/ freshwater users. Agriculture and freshwater aquaculture do not compete with marine water users. On the other hand, marine capture fishery or off-shore aquaculture does not affect freshwaters, agriculture or human settlements. The competition between marine water users and coastal land users such as human settlements/tourism 
is comparably low. As a young industry, shrimp culture competes for natural resources not only with coastal land users but also with fresh/sea and brackish water users. It should be emphasized that any new activity in the coastal area will necessarily bring about change. When there are conflicts among different sectors with different views whether they are scientifically proven or not, it will eventually become a mass outcry. The visualization of actual and hypothetical hazards and inadequate assessment of its positive impact have intensified this situation (Mishra \& Rath, 1999). Due to high visibility of the sector, complains made against shrimp culture industry by other coastal water and land users have created the negative image of the industry without considering the scientific facts.

Until last two - three decades, estuarine systems and wetlands were regarded as wasteland by governments and international agencies and encouraged private sector development for aquaculture and other enterprises (Boyd, 1999). In comparison with other aquaculture ventures, shrimp culture plays a considerably greater role in national development, by bringing in foreign exchange, stimulating infrastructure development and serving to reclaim unproductive areas (Weidner \& Rosenberry, 1992; Liao, 1994; Lin, 1995; Singh, 1999; Kautsky et al., 2001). There are many examples of sustainable shrimp farming operations in existence (Singh, 1999) and it is one industry that uses the least amount of chemicals harmful to man and other animals. Despite claims to the contrary, it appears that shrimp farming can create relatively high levels of employments per unit area of land compared to most other feasible alternatives.

Most of the problems result from shrimp culture as it is a new and rapidly growing industry for which technology and management methods are being developed as it grows. Over the past years, environmental awareness has grown all over the world. Consumers and business buyers have become increasingly interested in environmentally sound products and services. Therefore, efforts to provide a reasoned, balanced view of shrimp culture activities and the promotion of the benefits of aquaculture products grown in a sustainable manner are necessary (Kongkeo, 2001).

However, some of the negative publicity given to shrimp culture may be justified. The negative environmental impacts attributed to shrimp culture most often have resulted from poor planning, inappropriate site selection, poor management procedures, and lack of attention to environment protection and well being (Boyd et al., 1998). The need to learn from experiences on ecologically unsustainable development and to prevent its repetition on a global basis has been generally accepted. The bulk of the environmental impacts are due to the farming activities and 
this sector probably is the least organized of the industry sectors (Fegan, 1996). Aquaculture producers are affected more directly by the negative environmental impacts of their own production activities in terms of reduced profits (or increased production costs) compared to producers in other industries (Asche et al., 1999). Therefore, the image of the industry and its future may be affected unless it deals effectively with environmental issues.

The negative image created by the popular press should be considered seriously and appropriate management strategies should be adopted to minimize the negative impacts of the industry. Due to unavoidable competition for resources with other highly organized sectors in the coastal areas shrimp culture will further be a challenging enterprise for at least several years unless more scientific studies are carried out to show the possible favorable and unfavorable interactions among shrimp culture and the natural coastal environment. The magnitude of environmental documents that has been propagated in media is not exactly correct. Besides, now funding agencies (Asian Development Bank, World Bank etc.) have advised the farmers to mitigate such damages if any.

\section{REFERENCES}

Aitken, D. 1990. Shrimp farming in Ecuador: An aquaculture success story. World Aquaculture 21: 7-16.

Alongi, D. M., F. Tirendi \& L. A. Trott. 1987. Rates and pathways of benthic mineralization in extensive shrimp ponds of the Mekong delta, Vietnam. Aquaculture 175: 269-292.

Anon. 2000. State of Asian aquaculture. Aquaculture Asia V(I): 4-24.

Anon. 2001. Shrimp 2001, Chennai, India. Infofish International 4: 17.

Asche, F., A. G. Guttermsen \& R. Tveteras. 1999. Environmental problems, productivity and innovations in Norwegian salmon aquaculture. Aquaculture Economics and Management 3:1-5.

Beveridge, M. C. M., M. J. Phillips \& D. J. Macintosh. 1997. aquaculture and the environment: the supply of and demand for aquacultural goods and services by Asian aquaculture and the implications for sustainability. Aquaculture Research 28: 797-807.

Boyd, C. E., L. Massaut \& L. J. Weddig. 1998. Towards reducing environmental impacts of pond aquaculture. Infofish International 2: 27-33. 
Boyd, C. E. 1999. Aquaculture sustainability and environment issues. World Aquaculture 30: 27-37.

Browdy, C. L., D. Bratvold, J. S. Hopkins, A. D. Stokes \& P. A. Sandifer. 2001. Emerging technologies for mitigation of environmental impacts associated with shrimp aquaculture effluents. Asian Fisheries Science 14: 255-267.

Burford, M. A. \& M. P. Preston. 1998. Tropical micro algae - their potential for rearing shrimp larvae. In: The Third Asian Fisheries Forum (L. M. Chou, A. D. Munro, T. J. Lam, T. W. Chen, L. K. K. Cheng, J. K. Ding, K. K. Hooi, H. W. Khoo, V. P. E. Phang, K. F. Shim \& C. H. Tan, eds). Asian Fisheries Society, Manila, Philippines. 775-777 pp.

Chamberlain, G. W. 2001. Sustainable shrimp farming: Issues and non issues. In: Production and marketing of shrimp: trends and outlook. (S. Subasinghe and T. Singh, ed.). Proceedings of shrimp 2001 Chennai, The Fourth World Conference on the shrimp industry and trade and buyer-seller meet, 27-29 Sept. 2001, Chennai, India. 27-29 pp.

Clifford, H. C. 1985. Semi intensive shrimp farming. In: Texas shrimp manual (G. W. Chamberlain, M. G. Haby \& R. J. Miget, eds). Texas agricultural extension service, Texas IV: 110-137 pp.

Clifford, H. C. 1992. Marine shrimp pond management: A review. In: Proceedings of the special session on shrimp farming (J. Wyban, ed.). World Aquaculture Society. USA. 110-137 pp.

Eng, C. T., P. N. James \& Y.F. Guarin. 1989. The environmental impact of aquaculture and the effects of pollution on coastal aquaculture development in Southeast Asia. Marine Pollution Bulletin 20(7): 335-343.

FAO. 1997. Aquaculture Development. FAO Technical Guidelines for Responsible Fisheries. No. 05. Rome. 40 pp.

FAO. 2002. Fishstat Plus, Version 2.30. CD Rom. Food and Agriculture Organization, Rome.

FAO . 2007. State of World Fisheries and Aquaculture 2006, ISSN 1020-5489. FAO Fisheries and Aquaculture Department, Food and Agriculture Organization, Rome.

Frederiksen, T. M., K. B. Sorenses, K. Finster \& D. J. Macintosh. 1998. Implications of shrimp pond waste in mangrove environment. Aquaculture Asia III(2): 8-11.

Fegan, D. F. 1996. Sustainable shrimp farming in Asia: Vision or pipedream? Aquaculture Asia 1(2): 22-28. 
Folke, C \& N. Kautskey. 1992. aquaculture with its environment: Prospects for sustainability. Ocean and Coastal Management 17: 5-24.

Hopkins, J. S. \& J. Villalon. 1992. Synopsis of industrial panel input on shrimp pond management. In: Proceedings of the special session on shrimp farming (J. Wyban, ed.). World Aquaculture Society. USA. 138-142 pp.

Jayasinghe, J. M. P. K. 1995. Country Report: Sri Lanka. FAO/ NACA Regional study and workshop on the environmental assessment and management of aquaculture development, Network of Aquaculture centres in Asia-Pacific, Bangkok, Thailand. 357-376 pp.

Josupeit, H. 2001. An overview of the world shrimp market. In: Aquaculture in the Third Millennium (R. P. Subasinghe, P. Bueno, M. J. Phillips, C. Hough, S. E. McGladdery and J. R. Arthur, eds). Technical Proceedings of the Conference on Aquaculture in the Third Millennium, Bangkok, Thailand. 1-6 pp.

Kautsky, N., R. Patrik., M. Tedengren, \& M. Troell. 2000. Aquaculture. Ecosystem perspectives on management of disease in shrimp pond farming. 145 - $161 \mathrm{pp}$.

Kautsky, N., C. Folke, P. Ronnback, M. Troell, M. Beveridge \& J. Primavera 2001. Encyclopedia of Biodiversity, Volume 1. Academic Press. 185 - 198 pp.

Kongkeo, H. 2001. Current status and development trends of aquaculture in Asian region. In: Aquaculture in the Third Millennium. (R. P. Subasinghe, P. Bueno, M. J. Phillips, C. Hough, S. E. McGladdery and J. R. Arthur, eds.). Technical Proceedings of the Conference on Aquaculture and the Third Millennium, Bangkok, Thailand. 265-266 pp.

Liao, I. C. 1994. Prawn culture toward 2002: Focus on Asia. In: The Third Asian Fisheries Forum. Manila, Philippines. 973-984 pp.

Liao, C. 1996. Aquaculture of crustaceans. In: Perspectives in Asian Fisheries (Sena S. De Silva, ed.). Asian Fisheries Society, Manila, Philippines. 303 p.

Lin. K. C. 1995. Progression of intensive marine shrimp culture in Thailand. Swimming through troubled water. In: Proceedings of the Special Session on Shrimp Farming, Aquaculture '95 (C. L. Browdy \& J. S. Hopkins, eds.). World aquaculture Society. Lousiana, USA. 13-23 pp.

Macintosh, D. J. 1996. Mangroves and coastal aquaculture: Doing something positive for the environment. Aquaculture Asia 1(2): 3-8. 
Macintosh, D. J. \& M. J. Phillips. 1992. Environmental issues in shrimp farming. In: Proceedings of the Third Global Conference on the Shrimp Industry (H. D. Saram \& T. Singh, eds.). 14-16 Sept, Hongkong. 119-145 pp.

McPee, D. P. 2001. A comparison of discharge quality and quantity into Wueensland east coast catchments. A report prepared for the Australian Prawn Farmers Association. 49 pp.

Menasveta, P. \& A. W. Fast. 1998. The evolution of shrimp culture and its impact on mangroves. Infofish International 1: 24-29.

Mishra, S. \& S. C. Rath. 1999. Environmental implications of aquaculture. Aquaculture Asia IV(4): 33-36.

Ninawe, A. S. 1999. Coastal aquaculture versus environment: pros and cons. Infofish International 2: 43-47.

Paez-Osuna, F. 2001. The environmental impact of shrimp aquaculture: a global perspective. Environmental Pollution 112: 229-231.

Pongthanpanich, T. 1996. Economy study suggests management guidelines for mangroves to derive optimal economic and social benefits. Aquaculture Asia 1(2): 16-17.

Primavera, J. H. 1997. Socioeconomic impacts of shrimp culture. Aquaculture Research 28: 815-827.

Primavera, J. H. 1998. Tropical shrimp farming and its sustainability. In: Tropical Mariculture (S. S. De Silva, ed.). Academic Press, California, USA. 258-308 pp.

Purwaka, T.H. 2002. Coastal resources management in Indonesia: legal and institutional aspects. ICLARM Technical Report. No. 60. ISBN 983-2346-150. WorldFish Center, 60-90 pp.

Robertson, A. I. \& M. J. Phillips. 1995. Mangroves as filters of shrimp pond effluent: predictions and biogeochemical research needs. Hydrobiologia 295: 311-321.

Shang, Y. C. \& C. A. Tisdell. 1997. Economic decision making in sustainable aquacultural development. In: Sustainable aquaculture (J. E. Bardach, ed.). John Wiley and Sons, Inc. USA. 127-148 pp.

Silas, E. G. 1987. Significance of the mangrove eco system in the recruitment of fry and larvae of finfishes and crustaceans along the east coast of India. Report of the workshop on the conversion of mangrove areas to aquaculture. Iloilo, Philippines, 24-26 April. UNDP/ UNESCO, New Delhi. 19-34 pp. 
Singh, T. 1999. Benefits of sustainable shrimp culture. Infofish International. 3: 25-32.

Subasinghe R. \& U. Barg, 1998. Challenges to health management in Asian aquaculture. Asian Fisheries Science 11: 177-193

Thia-Eng, C. 1989. Developing coastal area management plan in the Southeast Asian region. Proceedings of the Sixth Symposium on Coastal and Ocean Management, July 11-24, Charleston, SC. 2192 p.

Treece, G. D. 2000. Shrimp culture. In: Encyclopedia of Aquaculture (R. R. Stickney, ed.). John Willey \& Sons, Inc. USA. 798-865 pp.

Weidner, M. J. \& B. Rosenberry. 1992. World shrimp farming. Proceedings of the Special Session on Shrimp Farming (J. Wyban, ed.). World Aquaculture Society, USA. 1-21 pp.

Williams, M. J. 1997. Aquaculture and sustainable food security in the developing world. Sustainable aquaculture (J. E. Bardach, ed.). John Wiley \& Sons, Inc. USA. 15-52 pp.

Yamamoto, T. 1992. Aquaculture in Asia: The 1989 APO aquaculture survey. In: Proceedings of the 1990 APO Symposium on Aquaculture (C. Liao, S. Shyu \& N. Chao, eds). Taiwan Fisheries Research Institute. 127-199 pp. 